\title{
Prisoners in the community: the open prison model in Catalonia
}

\author{
Marta Martí, PhD in Law (Criminology), \\ Universitat Pompeu Fabra, Spain
}

\begin{abstract}
Open prisons are low-security penitentiary institutions in which life conditions are less strict than in closed prisons, and where prisoners have more contact with the outside world. Despite sharing important features, some variations can be found in the model of open prisons in different countries. This article describes the Catalan open prison model, characterized by the fact that prisoners serve the sentence in full semi-liberty; that is, by day they work and spend time with their families or doing other activities, but return to prison to sleep. As a contribution to the comparative study of open prisons, I describe here how Catalan open prisons are run and discuss the concept of 'openness' with reference, above all, to the open prisons that exist in Scandinavian countries. This work shows that the degree of openness of open prisons varies considerably between different countries - therefore approaching community penalties or closed prisons in a greater or lesser extent - and suggests that the role that open prisons are granted in each penal system is part of the explanation. ${ }^{l}$
\end{abstract}

\begin{abstract}
Åbne fængsler har et lavere control-niveau end lukkede fængsler og indsatte i åbne fængsler har mere kontakt til verden uden for fængslet. Trods mange ligheder findes der også en del forskelle imellem åbne fængsler i forskellige lande. I denne

1. Marta Martí holds a PhD in Law (Criminology). Currently, she is working as an external consultant for the International Committee of the Red Cross in El Salvador and she is member of the Research Group in Criminology and Criminal Justice System of Universitat Pompeu Fabra (Spain). This article is based on her PhD dissertation, 'One foot in and one foot out: serving a prison sentence in an open prison', which was accepted in November 2018 in Universitat Pompeu Fabra (Spain). The full version of the dissertation (in Spanish) can be found on the following link: https://repositori.upf.edu/handle/10230/36320. This article is part of the project 'Ejecución y supervisión de la pena: calidad de la intervención, legitimidad y reincidencia' (DER2015-64403-P), funded by the Spanish Government.
\end{abstract}


artikel præsenteres åbne fængsler i Catalonien. Disse er kendetegnet ved at de indsatte rent faktisk nyder delvis frihed. Det indebærer, at de i dagtimerne går på arbejde uden for fængslet eller tilbringer tid sammen med deres familie eller er beskæftiget på anden måde i lokalområdet. Om aftenen vender de tilbage til fængslet og tilbringer natten dér. I artiklen sammenlignes de catalanske åbne fængsler med åbne fængsler i Skandinavien. Sammenligningen viser, at der er store forskelle i graden af åbenhed i åbne fængsler, nogle steder ligger de tættere på samfunds-straffe og andre steder langt tættere på lukkede fængsler. Der argumenteres for, at en del af forklaringen her på er, hvilken rolle i det samlede nationale straffesystem de åbne fængsler har i forskellige lande.

\section{Introduction}

Open prisons are low-security penitentiary institutions in which life conditions are less strict than in closed prisons, and where prisoners have more contact with the outside world. The aim of this type of prison is for the prisoners to serve their sentence under conditions that - to the extent that it is possible - resemble those of normal life, and to helping their future resettlement. Although the best-known open prisons are probably in Scandinavia (Birk 2011; Fransen 2017; Hornum 1988; Shammas 2014; 2015), prisons of this type also exist in many other countries such as the United Kingdom (Jones \& Stockford 1977), Spain (Cutiño 2015; Martí 2018) and India (Chakraburtty 2018).

There is little literature on the subject - in English, at least - as most studies on prisons tend to concentrate on closed prisons, in which prisoners are isolated from society and controlled by strictly regulated regimes. In addition, the study of open prisons in some countries is frequently included under the study of open institutions in general, leaving the specific characteristics of open prisons unobserved. As such, the reality of open prisons is poorly understood; indeed, even those with good knowledge of prison regimes might still ask: 'What is an open prison like?' 'What does serving a sentence in a prison of this type imply?' 'Are all open prisons the same?' The lack of studies on the subject means that there are no easy answers to these questions, which helps explain why currently comparative debate on the subject is all but absent.

This work consists of a description of the open prison model in Catalonia (Spain) that I hope will provide a contribution to the literature on open prisons and will help stimulate discussion on the subject. Catalan open prisons are characterized by the fact that prisoners serve the sentence in full semi-liberty, that is, by day they work or do other activities in the community and spend time with their families but return to prison to sleep. In the first section I describe the nature 
of these Catalan prisons and how prisoners are supervised; subsequently, I explore this concept of 'openness' in the Catalan prison system and use the Nordic model of open prisons as a comparison. This article is based on a literature review and on broad-ranging qualitative research performed in Catalonia, during which I interviewed both prison staff and inmates in three open prisons (Martí 2018).

\section{Open prisons in Catalonia}

To understand the Catalan model of open prisons it is first necessary to examine some of the general characteristics of the Spanish prison system. Catalonia is one of the 17 Autonomous Communities in Spain and shares with the other regions a common Penal Code and set of prison regulations (LOGP and RP). ${ }^{2}$ Nevertheless, certain areas of competence relating to prison sentences have been devolved to Catalonia and, in questions concerning the enforcement of prison sentences and community sanctions, the Catalan system differs from the rest of Spain. Given that this work concentrates on the Catalan experience, some of the issues concerning open prisons may differ from the situation in the rest of the State, even though the overall configuration of their prison systems is essentially the same in both Spain and Catalonia.

The Spanish penal system is a progressive and flexible system that divides sentences into three different levels or grades that correspond to different types of prisons and regimes (see Figure 1). Level one, which is similar to the English category A, is for prisoners regarded as dangerous, who are held in isolation in maximum security institutions or in maximum security wings in closed prisons; level two corresponds to English category B and C, and consists of an ordinary prison regime for the majority of prisoners, who serve their sentences in ordinary wings in closed prisons; level three, similar to the English category D, corresponds to people who are serving prison terms under open conditions. Towards the end of their sentences, third-level prisoners may be released on parole.

2. Ley Orgánica General Penitenciaria 1/1979, 26 September (LOGP); and Real Decreto por el que se aprueba el Reglamento Penitenciario 190/1996, 9 February (RP). 
Figure 1. Classification of prisoners in the Spanish prison system.

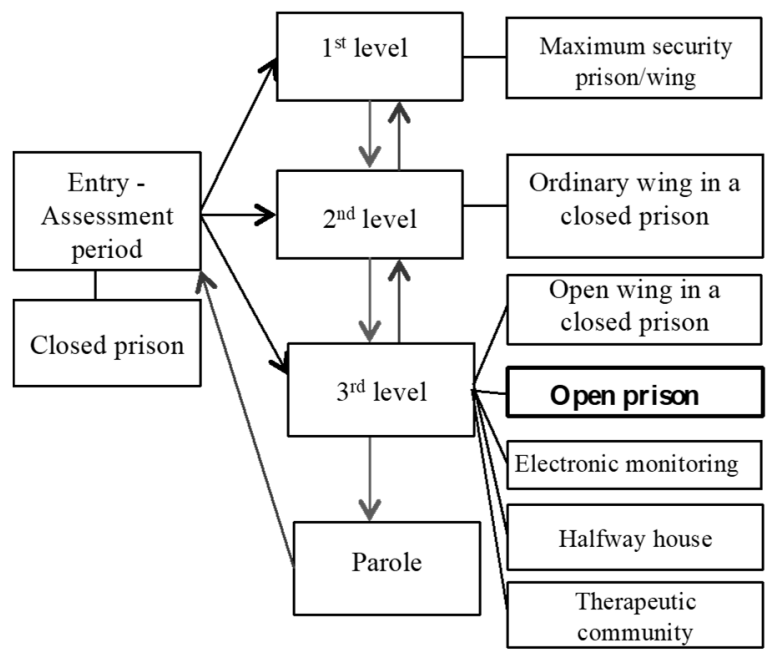

Source: Own work.

Given that it is a progressive and flexible system, prisoners do not have to pass through all levels and at the beginning of their sentence the prisoner is classified in any one of the three levels (except that of parole). Generally, the procedure is as follows: a prisoner is placed in a closed prison and, after assessment for up to two months - which in practice may be longer -, the Prison Board proposes a classification $^{3}$ and if necessary the prisoner is then moved to an appropriate facility. This classification is reviewed throughout a prisoner's sentence and they can change level - in either direction - depending on their behaviour.

Here, we will concentrate on the third level given that it is the level from which prisoners can serve their sentences in open conditions in Spain. ${ }^{4}$ The open

3. The level in which prisoners are classified is confirmed or rejected by the Catalan Directorate of Prisons. The prisoner and the prosecutor are entitled to appeal against the decision of the Catalan Directorate of Prisons to the prison judge.

4. On occasions the concept of 'open prison' is used in a broad sense to refer to penal institutions in which prisoners are in open conditions (e.g. Cid \& Ibàñez 2019). Here, we refer to these latter institutions as 'open institutions', thereby reserving the concept of an 'open prison' for independent prisons that house prisoners in semi-liberty. 
prisons in Catalonia are known as 'open centres' (centres oberts) and possess the following characteristics: a) they are independent institutions within the penitentiary system; b) their control mechanisms are minimized and the supervision of prisoners is based on trust and self-regulation; and c) prisoners are held in semiliberty: by day they live and work in the community but spend the night in prison.

As Figure 1 shows, in Catalonia (and in the rest of Spain) third-level prisoners can also serve their sentences in other types of open institutions that are not strictly speaking open prisons. These can be open wings in closed prisons for prisoners on day-release, therapeutic communities for prisoners being treated for drug-abuse, halfway houses that consist of ordinary flats or houses in urban or rural areas (generally for use by prisoners with low incomes subject or other special needs), and some form of electronic monitoring. Like other open institutions, open prisons have minimal supervision (compared to closed prisons) and their prisoners have regular contact with the outside world. Nevertheless, open prisons are different from open wings because they are independent institutions, whereas open wings depend on the closed prison, as they are a part of it both physically and economically, and in terms of its hierarchical organization. Likewise, open prisons differ from halfway houses, therapeutic communities and electronic monitoring, because in these latter cases prisoners live outside the prison, whilst in an open prison they still spend part of their day in prison where they have less autonomy and their movements are still controlled by prison guards. Here we examine the world of open prisons as one of the strictest ways of serving a sentence in open conditions.

\subsection{Who can be sent to an open prison and who serves time there?}

As mentioned above, in Catalonia to be sent to an open prison a person must first be classified as a third-level prisoner (English Category D). Given that the system is flexible, in theory there is no minimum time requirement for being classified at this level -once the prisoner has served the assessment period- and any convicted prisoner can be sent to an open prison at any time after their sentence begins. Nevertheless, the 2003 penal reform introduced exceptions to this rule in cases considered to be of exceptional seriousness, such as terrorism or sexual abuse of minors. In these instances, prisoners must have served at least half of their sentences in a closed prison if their sentence is for five years or more (Article 36, Spanish Penal Code). In 2015, life sentences were introduced, which prevents prisoners from being sent to open prisons until they have served at least 15 years of their sentences. Other than these time-based restrictions and certain additional requisites in cases of terrorism and criminal organizations, in Catalonia (and in Spain) there are no types of crime that preclude a prisoner from being sent to an open prison. 
Prison regulations state that to be sent to an open prison a prisoner must "have the ability to live a life in semi-liberty" (Article 63, LOGP) and, if the prisoner has been condemned to pay victim compensation, he or she must have either paid the full amount or be able to guarantee that they will pay when in semi-liberty.

In light of the above, current legislation is fairly generous and does not impose any excessively strict criteria regarding access to open prisons. In practice, when deciding whether or not a prisoner should be granted access to an open prison, Prison Boards take into account aspects such as the possibility that they will find work, their social and family background, their behaviour in prison (e.g. whether or not they have ever been sanctioned or disciplined), whether or not they have been granted prison leaves, and possible addictions that may be treatable with external care (see broadly Cid \& Ibàñez 2019; Cutiño 2015). Despite the lack of rigid legislation, studies show that in reality certain groups of prisoners are less likely to gain access to open prisons and other open institutions. For example, Cid \& Ibàñez $(2019,320)$ indicate that one of these groups are foreigners, especially those without residence permit who run the risk of being deported. Likewise, short-term prisoners ${ }^{5}$ or those who have served a large part of their sentences on remand (in pre-trial prison) are also unlikely to be able to enjoy the benefits of open prisons given that there is not enough time for them to be classified and to progress to open conditions (Cid \& Ibàñez 2019, 320).

It is worth noting that in Spain all prison sentences of less than two years can be suspended by the judge, so that the convicted person need not enter prison, although they may be obliged, for example, to report regularly to the police or court, or to enter a community service programme (Probation Service). In practice, according to the study of Varona (forthcoming) conducted in Catalonia, between the 70 and $80 \%$ of prison sentences up to 2 years are suspended. Nevertheless, once a prison sentence has not been suspended, there are no fast-track classification procedures for short-term prisoners or specific measures that enable prisoners facing short sentences to serve them in open prisons.

As of January 2018, there were 1,548 prisoners classified as level three in Catalonia, who represent $21.8 \%$ of all convicted prisoners. ${ }^{6}$ Of the 1,548 third-level

5. In Spain, legally short-term prison sentences are those of two years or less. The minimum sentence is three months in prison, although some people are obliged to enter prison for less time in the case of the non-payment of a fine.

6. $68.5 \%$ are level-two prisoners in closed prisons and $1.8 \%$ are level one in maximum-security institutions. 
prisoners, about 900 people were in open prisons ( $12 \%$ of all convicted prisoners), ${ }^{7}$ while the others were in other open institutions $(9.8 \%)$, for instance, with electronic monitoring or in halfway houses. The commonest offences committed by prisoners in open prisons are property-related offences (i.e. theft), offences against public health such as drug trafficking, or offences involving bodily harm (Justice Department statistics, 2019). In general these offences coincide with the commonest offences committed by the whole prison population and a priori there is no over- or under-representation of any type of offences in open prisons. Of the prisoners who entered open regimes in $2018,45.1 \%$ did so at the beginning of their sentences, while $54.9 \%$ did so having served a part of their sentence as second-level prisoners in a closed prison (Justice Department statistics, 2019). Finally, $54.4 \%$ of the sentences served by third-level prisoners are for less than five years (19.3\% are for less than two years), around $27.9 \%$ of sentences are for five or 10 years, and the remaining $17.7 \%$ are for over 10 years $^{8}$ (Justice Department statistics, 2019).

\subsection{What are open prisons like?}

Catalonia has four open prisons, ${ }^{9}$ which have three main features in an organizational and structural sense:

- Firstly, they are organizational and functionally independent of Catalonia's closed prisons, and have their own management boards and full decisionmaking autonomy. This independence allows these prisons to work more effectively and in more specialized ways (Cutiño 2015, 73) since they do not depend on resources provided by the closed prisons. Moreover, open prisons have Prison Boards on which members of the treatment teams and the prison management evaluate prisoners and have the final word on decisions relating to their treatment, including proposals to change a prisoners' classification and

7. Some of these prisoners are in the open wing of a prison in Barcelona but I decided to include them because this wing is run independently and these prisoners enjoy the same type of regime as prisoners in open prisons (see Marti 2019, pp. 228-229).

8. There are no data regarding the duration of the sentences of the prisoners that enter open prison from the start of their sentences or because of good behaviour. However, a study by Capdevila et al. $(2005,66)$ shows that if condemned to a sentence of more than four years it is very unlikely that a prisoner will enter an open prison right from the start of his/her sentence.

9. In Barcelona, Girona, Tarragona and Lleida. 
grant conditional releases - which have to be approved by the judge -, approval of treatment programs and the granting of extraordinary leaves.

- Secondly, open prisons are physically independent of closed prisons as the objective is to separate the former from the closed isolated penitentiary regimes that characterize the latter and to locate them in urban areas to facilitate contact with the local community. Nevertheless, although most open prisons in Catalonia are situated in cities and are well connected by public transport, most use facilities from former closed prisons that have been converted into open centres. Thus, the symbolism of the closed prisons remains present in the form of walls, observation towers, fences, bars and automatic sliding doors.

- Thirdly, staff in Catalan open prisons consist of treatment teams and prison guards (as well as the Prison Boards mentioned above). The treatment teams are in charge of prisoners' treatment and consist generally of social workers, lawyers, psychologists and experts who help prisoners in their search for employment. Prison guards maintain discipline and security and are not involved directly with questions regarding prisoners' treatment. This situation mirrors that of closed prisons throughout the Spanish penal system, in which securityand prisoner-treatment-related tasks have always been performed by separate groups of professionals. Nevertheless, this separation is more blurred in open prisons, where guards are expected to avoid using authoritarian methods of control and play a more active role in the rehabilitation of prisoners. One good obvious example of this is that prison guards in open prisons - unlike their counterparts in closed prisons - do not wear uniforms.

\subsection{What does it mean to serve a sentence in on open prison?}

Prisoners in Catalonia's open prisons spend most of the day outside the prison and so most of the supervision is carried out within the community. ${ }^{10}$ More specifically, prisoners serve their sentences in conditions of full semi-liberty, meaning that they almost literally spend half of their time in the community and the other

10. Criminological literature uses the concept of 'supervision' to analyse sentences that are essentially served in the community (see McNeill \& Beyens 2014; McNeill, Raynor \& Trotter 2010). Supervision involves both intervention designed to help in the rehabilitation of the prisoner - for example, via treatment programmes - and control measures that ensure that the prisoner comply with the conditions of his or her sentence, which may include checks on drug use. Open prisons are halfway between the prison and the community, and so the supervision of the prisoners (i.e. rehabilitation and control) involves measures from both the prison and the community penalties context (i.e. the Probation Service). 
half in prison, except at weekends, which they spend at home. Although a prisoner's exact timetable will depend on their job and routine, they generally leave at 8-9 am and then return to prison - where they must spend at least eight hours - at $8-9 \mathrm{pm}$. All prisoners are obliged to leave prison every day as the time they spend in open conditions is regarded as preparation for life after prison. The idea is that being incarcerated day-after-day is no preparation for post-prison life and so prisoners must venture out to 'earn a living on the outside'. Thus, in Catalan open prisons inmates are usually not allowed to stay in the prison when they should be outside nor may they come back before their set return time unless they are working inside the prison, for example, on prison maintenance.

Taking into account each prisoner's characteristics, the treatment teams draw up individualized plans that detail the duties designed to their treatment. Criminological studies suggest that the factors that most influence prisoners' desistance from crime are work, housing, the use of drugs and the family situation (see a complete summary in LeBel \& Maruna 2012). In a similar way, and according to the Instruction 1/2007 from the Catalan Directorate of Prisons, intervention in Catalan open prisons is organized in the five areas that I describe below:

- The personal area, which embraces possible addictions, health-related concerns and violence. Prisoners who are thought to require intervention in one of these areas may be obliged to attend a rehabilitation centre or a health clinic, or may have to undertake specialized programmes designed to prevent sexual and gender-based offences.

- The work or training area is the most important aspect of open prisons and most prisoners are obliged to work, job-seek or enrol on training courses. Most prisoners work outside the prison in construction work, in bars and restaurants or as bus- or taxi-drivers, while a few are employed inside the prison as cleaners or repair workers. Prison social workers highlight that one of their main tasks is to help prisoners overcome the additional obstacles that prisoners have to confront when trying to find work (i.e. criminal records).

- The social-family area provides support to the prisoner's family, above all with respect to accommodation and financial questions. Prisoners may be obliged to try and improve their relationships with their children, act as a responsible family member, or find suitable housing. If necessary, social workers can put prisoners in touch with the local social services or other community-based institutions that will help find accommodation for homeless people or assist immigrants with applications for residence permits. 
- The reparation area is concerned with ensuring that prisoners pay all the compensation to the victim that they were sentenced to pay, as this is one of the conditions for being allowed to stay in an open prison. One of the commonest obligations of prisoners is to keep abreast of payments and present the prison treatment teams with proofs of payment.

- Finally, the institutional area works to ensure that prisoners adapt to both prison regulations and life in the community. This area focuses above all on long-term prisoners who have been imprisoned in closed prisons for a long time and so find it much harder to adapt to life in semi-liberty. This work often involves teaching new technologies and how to use public transport, and encouraging prisoners to take decisions for themselves.

Furthermore, beyond these areas of intervention, serving a sentence in an open prison means being supervised by members of the treatment team and prison guards both when prisoners are inside the prison and when they are working in the community. Although the rigour of the security measures is less than in closed prisons and there is more trust and self-responsibility, prisoners are still subject to control and supervision. Prison staff ensure that prisoners fulfil their obligations in the intervention areas outlined above. For example, prison staff are in permanent contact with the social and health services and other external bodies where prisoners are being treated, and keep a careful watch on their attendance records and behaviour. Likewise, prisoners with addiction-related problems and those who return to prison showing evident signs of having taken drugs are subject to controls for drug and alcohol consumption. In the work area, for example, prisoners must present a job contract when they find a job and then all of their monthly pay slips. Open-prison staff can contact prisoners' work supervisors by telephone or personally to check that they are fulfilling their work-related obligations. If prisoners decide not to give details to their employers about their prisoner condition, prison staff typically will supervise them in other ways by, in the case of a bar worker, 'dropping by to have a coffee'.

Beyond the controls that ensure that prisoners complete their treatments, in open prisons there are also a number of other regulations that must be obeyed. The most important norm is that the prisoner must return to the prison during the week to sleep every night. Thus, the control of times of arrival and departure is of great importance: when a prisoner returns to the centre, the prison guards check that they are on time and are then sent for a security check. Prisoners must place in lockers all objects that are not allowed in the prison (mobile phones with cameras, personal computers and tablets, alcohol, cutlery, food, rucksacks and so 
forth), then pass through a metal-detector and, in some cases, be tested for drug or alcohol consumption. After this, the guard opens the gate and the prisoner returns inside, where he or she must obey the internal regulations: no drug or alcohol use, no noise at night, no use of mobile phones with cameras or internet, and tidy cells. ${ }^{11}$ Even though the supervision in open prisons is more relaxed than in a closed prison, prisoners' freedoms are still restricted in a number of ways. ${ }^{12}$

In conclusion, serving a sentence in an open prison in Catalonia does not consist simply of 'going to prison to spend the night' as prisoners have to fulfil a series of obligations that - according to the prison system - aim to help in their rehabilitation, and they are subject to a series of supervisory measures. These measures and obligations, as we have seen, do not only apply during the time prisoners spend in the prison at night, as they have to be followed when prisoners are in the community on the daytime. In short, prisoners are supervised both inside and outside the prison. In open prisons, prisoner control is more diffuse than in traditional prisons but it does not necessarily mean that it is not intrusive or demanding or does not inflict pain on prisoners (Crewe 2011; Shammas 2014). In this context, in open prisons, supervision may be intrusive as prison staff are required to intervene in a prisoner's work and family life, and a prisoner will have to obey a set of rules that they may not agree with or that they feel is 'nobody else's business'. On the other hand, this relative lack of direct control and supervision in open prisons obliges prisoners to have more self discipline since, unlike prisoners in closed prisons, there are real opportunities for escape (Birk 2011, 7). Thus, in open prisons control mechanisms are based on trust and a prisoner's sense of responsibility, and prisoners 'are forced to strive for self-improvement' (Shammas 2014, 117). In addition, semi-liberty represent a double-edged sword for some prisoners, as 'the beguiling fruits of liberty - the possibility to drink alcohol, taking drugs, and developing intimate relationships - become honey traps of risks'; adding greater responsibility onto the prisoners to self-regulate their desires (Crewe 2015, 56).

11. Male and female prisoners might serve the sentence in the same open prison but in separate wings.

12. In order to supervise their life in the outside world, prisoners are interviewed regularly by prison staff. On the basis of these interviews and the other above-mentioned control measures, the Prison Boards evaluate whether or not prisoners are to be released on parole or, if they are not fulfilling their obligations or have committed an offence, will be sent back to a closed prison. 


\section{Discussion: some thoughts on the openness of open prisons}

As the international literature states, open prisons in general have four recognizable elements: they are still prisons and conform to the notion of a penitentiary institution as there are prison guards, curfews, or counts and checks; they are physically and administratively independent and separate from closed prisons and operate as such; they have fewer control measures and more 'normal' living conditions; and prisoners have frequent contact with the outside world, which gives them more freedom but demands of them more self-responsibility and selfdiscipline.

Different types of open prisons exist as each country's penal system develops a model regarding the above-mentioned feature that most suits it. We have already described the open prison system in Catalonia whose principal characteristic is that prisoners have a significant degree of contact with the outside world: all leave in the morning and do not - indeed, they cannot - return until the evening. In this way, a large part of the sentence is served outside the prison and, moreover, prisoners are obliged to become involved in the local community: most work or look for work in conventional businesses or services, use the public health services, look after their families by, for example, taking their children to school or, if time and distance permit, by doing household chores and spending time with family members before returning to prison.

The Catalan open prison system operates only with this type of prisoner and does not accept people in semi-liberty whose movements are more restricted and who are not allowed to leave the prison every day or for the whole day. This type of prisoner resides in open or semi-open wings in closed prisons. Some professionals believe that this lack of facilities for prisoners in a restricted semi-liberty in open prisons may hinder individualized supervision. For example, when a person who is serving the sentence in an open prison defaults on his or her obligations but not in a serious way that would warrant his or her being returned to a second level - and so being moved to an ordinary wing in a closed prison - the law states that this prisoner could retain the third-level category but in a situation of restricted semi-liberty (Article 82, RP). However, given that the current Catalan open prison system does not have any semi-open units, returning prisoners to a situation of restricted semi-liberty necessarily means that they will be moved to a closed prison (albeit - possibly - to an open wing). Some professionals believe that in certain situations a revocation of this magnitude is out of proportion with some misdemeanours and that, moreover, moving to a closed prison represents an interruption of the treatment they are receiving in the open prison. Thus, some 
professionals advocate the setting up of semi-open (or semi-closed) wings in open prisons:

"I for one think that it would be a good idea to have here prisoners with restrictions because I think that it's not necessarily a step backwards. Sometimes, with a few more restrictions but without changing prisons we can continue working on some of the things that we have already begun. Continuity like this wouldn't be a bad thing. Even if you pass on the information to your colleagues [in the closed prison], some details always get lost on the way. As well, going back to a closed prison is always a heavy blow for prisoners, even if they are sent to an open wing" (Fragment of an interview to an open prison social worker).

Additionally, the possibility of having semi-open wings in open prisons would also make it possible for prisoners to serve there the short sentences that are currently served in closed facilities. As has been commented above, the initial classification of prisoners - which in Catalonia takes place in closed prisons - on occasions takes so long that short-term prisoners actually serve their sentences before they are classified (Cid \& Ibàñez 2019, 320), which means that they serve their whole sentences in closed prisons. ${ }^{13}$ To speed up the classification process and so stop these people from entering closed prisons, it has been suggested that shortterm prisoners should enter directly into open prisons ${ }^{14}$ and that their initial classification should take place under open conditions (Capdevila et al. 2014, 245). Even so, some professionals defend the current model and believe that this proposal is unviable because it would oblige open prisons to have closed wings and to adopt security measures for these prisoners resembling those of closed prisons, which would pervert the 'purity' of the current model of Catalan open prisons. ${ }^{15}$

13. There are not pre-trial prisons in Spain, and detained prisoners are (ideally) incarcerated in specific wings of closed prisons (for a maximum of two years), even though some of them are transferred to ordinary wings.

14. The concept of a suspended sentence designed to avoid prison entry exists in Spain and is decided by a judge (see p. 5). I am referring here to those administrative measures that can be taken to make it more likely that a sentence may be completed under open conditions when the judge has not suspended it.

15. Another option would be to classify directly prisoners with short sentences as third-level prisoners who will complete their sentences in open prisons. Nevertheless, a common view in the Catalan prison system is that access to open prisons should be determined by the profile of every prisoner, and that a short sentence does not necessarily mean that a prisoner will be capable of living in semi-liberty. 
The possibility of making the initial classification of a prisoner in open prisons would hinder the functioning of these institutions, as they would suddenly need more security because these prisoners would initially be subject to an ordinary regime. That's to say, we would need a closed prison space within the open prison. The prison would no longer be a pure open institution. If this proposal prospers, it is tantamount to saying that although it is an open prison it has the capacity to be a closed prison. I don't think that the two things should be mixed; I think that the open prison system should be kept totally separate from the ordinary and closed regimes (Fragment of an interview to an open prison Director).

Not all open prisons are as open or as 'pure' as they are in Catalonia. For example, in some Scandinavian countries open prisons, which have around $30 \%$ or even $60 \%$ of the country's prison populations, house prisoners subject to more restrictive regimes of semi-liberty who have less contact with the local community than in Catalonia. Although there may be differences between countries, in general open prisons in Nordic countries are characterized by low levels of static security, meaning little guard against escape and considerable freedom of movement within the prison area (Fransen 2017, 82). As well, there are generally no bars or security fences, prisoners may have their own single room and have the keys to this room, and there are no restrictions on hours to watch television or visiting other prisoners in their rooms (Hornumm 1988, 71 referring to Sweden and Denmark). In Nordic open prisons, prisoners usually have the chance to be granted to prison leave to visit their families or their doctors, to go to the supermarket or take part in sporting events, although most often these activities - with a general exception regarding family visits - are supervised by prison staff (see Reiter et al. 2017, 495; Shammas 2015, 6). Likewise, some prisoners may be allowed to leave the prison to go to work, but typically the prisoners work in the prison or nearby, inside the prison area.

As is observed, open prisons in Scandinavian countries are slightly different from those in Catalonia (see Figure 2). Although both types of open prison are situated somewhere between closed prisons and community sanctions (a fact that guarantees that they have a special place within the penal system), Catalan and Nordic open prisons seem to be at different places on the same route since their openness vary considerably. On the one hand, Catalan open prisons grant the local community a central role in the (expected) rehabilitation of prisoners (which does not mean that there is any lack of control or absence of punishment) and does not allow prisoners to remain in the penal facility by day. On the other hand, Nordic open prisons promote contact with the outside world less frequently and less intensely as it commonly takes places within the prison area or under the supervision of prison officers, and they emphasize the normalization of life conditi- 
ons inside the prison perimeter (about the principle of normalization, see Fransen 2017; Reiter et al. 2017). Therefore Fransen $(2017,99)$ claims that Danish open prisons have never reached the level of openness that was initially hoped for and that indeed in recent years they have undergone a series of changes that have led them to have only a 'qualified degree of openness'. For example, this author states that open prisons have been fenced in with the creation of semi-open spaces and remand prison units established within the open prisons, with large fences, tight security and small 'cages' for short spells of outdoor yard time (Fransen 2017, 99).

Figure 2. Open prison system in Catalonia 2018 and Denmark $2017^{16}$

\begin{tabular}{|c|c|c|}
\hline & Catalonia & Denmark \\
\hline $\begin{array}{l}\text { Prison population rate } \\
\text { (per } 100,000)\end{array}$ & $\begin{array}{l}110 \\
\text { (source: Catalan Department of } \\
\text { Justice) }\end{array}$ & $\begin{array}{l}63 \\
\text { (source: Walmsley 2018) }\end{array}$ \\
\hline Prisoners in open prisons & $12 \%$ & $50,3 \%$ (in average in 2017 ) \\
\hline $\begin{array}{l}\text { Prisoners in other open } \\
\text { institutions }\end{array}$ & $9,8 \%$ & $\begin{array}{l}8 \% \text { (Halfway-houses) ( } 178 \text { per- } \\
\text { sons out of } 2262 \text { persons being } \\
\text { incarcerated after having been } \\
\text { sentenced). ( } 129 \text { incarcerated } \\
\text { asylum seekers are not inclu- } \\
\text { ded) }\end{array}$ \\
\hline $\begin{array}{l}\text { Access to open prisons: } \\
\text { decision }\end{array}$ & $\begin{array}{l}\text { General Prison Service (prior } \\
\text { Prison board proposal) }\end{array}$ & $\begin{array}{l}\text { As a main rule all sentences of } 5 \\
\text { years length (more than } 90 \% \text { of } \\
\text { all sentences) or shorter are ser- } \\
\text { ved in open prison. }\end{array}$ \\
\hline $\begin{array}{l}\text { Access to open prisons: } \\
\text { requirements }\end{array}$ & $\begin{array}{ll}- & \text { Good behaviour } \\
- & \text { Guarantee of victim com- } \\
& \text { pensation payment } \\
- & \text { Exceptional (serious } \\
& \text { crimes): } 1 / 2 \text { sentence served } \\
& \text { in a closed prison }\end{array}$ & $\begin{array}{l}\text { Sentence under } 5 \text { years length } \\
\text { No risk of radicalism or violent } \\
\text { behaviour } \\
\text { No risk of escape }\end{array}$ \\
\hline
\end{tabular}

16. The case of Denmark is taken as an example of the Scandinavian prison system. Nevertheless, some of the mentioned features about Denmark can be different in other Nordic countries. When nothing else is said the numbers about Denmark is from the yearly statistics published by the Danish Prison and Probation Service https://www.kriminalforsorgen.dk/wpcontent/uploads/2018/12/kriminalforsorgens-statistik-2017-2-udgave.pdf 


\begin{tabular}{|c|c|c|}
\hline $\begin{array}{l}\text { Type of prison where the } \\
\text { classification process } \\
\text { takes place in }\end{array}$ & $\begin{array}{l}\text { Closed prisons (including short } \\
\text { sentences) }\end{array}$ & $\begin{array}{l}\text { Pre-trial prison, closed prison or } \\
\text { by the prison administration af- } \\
\text { ter conviction but before incar- } \\
\text { ceration }\end{array}$ \\
\hline Prison officers & Yes (ununiformed) & Yes (uniformed) \\
\hline Treatment staff & $\begin{array}{l}\text { Yes (social workers, a lawyer, a } \\
\text { psychologist and an expert in } \\
\text { search of employment) }\end{array}$ & $\begin{array}{l}\text { Yes (social worker, teacher, } \\
\text { drug treatment, nurse, if possib- } \\
\text { le a psychologist few hours per } \\
\text { month) legal expertise is shared } \\
\text { between several institutions }\end{array}$ \\
\hline $\begin{array}{l}\text { Contact of prisoners with } \\
\text { the community (out of the } \\
\text { prison perimeter) }\end{array}$ & Daily, in all cases & $\begin{array}{l}\text { On prison leaves when they are } \\
\text { granted }\end{array}$ \\
\hline Daily routine of prisoners & $\begin{array}{l}\text { From } 8 \text { am to } 8 \text { pm (approx.) } \\
\text { prisoners work or do other acti- } \\
\text { vities in the community, out of } \\
\text { the prison area and without di- } \\
\text { rect supervision }\end{array}$ & $\begin{array}{l}\text { There is a duty of being occupi- } \\
\text { ed with work, school or treat- } \\
\text { ment (for addiction) } 7 \text { hours per } \\
\text { day except weekends. } \\
\text { Occupation takes place in the } \\
\text { prison }\end{array}$ \\
\hline $\begin{array}{l}\text { Prisoners working inside } \\
\text { the prison area }\end{array}$ & Exceptional & Normal \\
\hline Curfew & $\begin{array}{l}\text { From } 8 \text { pm to } 8 \text { am (approx.) } \\
\text { prisoners must be inside the pri- } \\
\text { son wing }\end{array}$ & $\begin{array}{l}\text { From app. } 5 \text { pm to } 8 \text { am priso- } \\
\text { ners must be in the wing. From } \\
\text { app. } 20 \text { (or } 21 \text { ) pm to } 7 \text { am pris- } \\
\text { oners are locked up in the cells }\end{array}$ \\
\hline $\begin{array}{l}\text { Level of autonomy inside } \\
\text { the prison area }\end{array}$ & Medium & $\begin{array}{l}\text { Medium in regard to cooking, } \\
\mathrm{TV} \text {, doing laundry etc. }\end{array}$ \\
\hline $\begin{array}{l}\text { Weekends and local and } \\
\text { national holidays }\end{array}$ & At home (no direct supervision) & In prison unless on prison leave \\
\hline $\begin{array}{l}\text { Prison leaves and activi- } \\
\text { ties outside the prison area }\end{array}$ & $\begin{array}{l}\text { No direct supervision by prison } \\
\text { officers }\end{array}$ & $\begin{array}{l}\text { Depending on risk assessment. } \\
\text { Either no supervision or com- } \\
\text { pany by staff member }\end{array}$ \\
\hline $\begin{array}{l}\text { Closed units within the } \\
\text { open prison for prisoners } \\
\text { with restricted semi- } \\
\text { freedom }\end{array}$ & $\begin{array}{l}\text { No - and open units in closed } \\
\text { prisons for prisoners being pre- } \\
\text { pared for transfer or in other } \\
\text { cases (for instance geography) }\end{array}$ & $\begin{array}{l}\text { Yes - and vice versa open units } \\
\text { in closed prison for prisoners } \\
\text { being prepared for transference } \\
\text { or in other cases (for instance } \\
\text { geography) }\end{array}$ \\
\hline
\end{tabular}

Source: Own work 
As it can be seen, openness in Catalonia prisons means having prisoners in the community, whereas openness in the Nordic countries does not necessarily imply such an involvement of prisoners in and with the community. In this way, as Cohen $(1979,345)$ stated, 'it becomes difficult to distinguish a very 'open' prison with liberal provisions for work release, home release, outside educational programs - from a very 'closed' halfway house', which could be the case of Catalonia. Similarly, in - at least some of - the Nordic countries, it may become difficult to distinguish a very 'open' closed prison from a very 'closed' open prison. By the same token, Lappi-Sepälä $(2019,108)$ states that there is a recent tendency in Finland to employ electronic monitoring technique as part of supervision in open prisons, 'blurring the borders between this two types of institutions'. Indeed, the limits between penal institutions are blurred and confused (Cohen 1979, 345) and it certainly becomes hard to resolve when a prison starts to be open, when it keeps being closed and when it stops being a prison.

Assuming the above considerations, the degree of openness of open prisons seems to be an important element when looking into open prisons in different countries and the number of prisoners serving their sentence in them. As we have seen, the openness of Catalan open prisons is very 'generous' but they only have around the $12 \%$ of prison population (although $21.8 \%$ of all convicted prisoners are in open conditions, see above part 2.1). Moreover, the impossibility of placing more restrictions on people in open prisons is sometimes seen as a limiting factor that prevents open regimes being applied to more prisoners. From the opposing point of view, the number of prisoners in Nordic open prisons is much higher: in Denmark most people serve their sentences in open prisons (Olesen \& Storgaard 2016, 50) and in 2017 an average of 50.3\% of prisoners were in open prisons (see figure 2); in Norway, approximately a third of all prisoners are in open prisons (Shammas 2015, 3), and in Finland about 40\% of convicted prisoners serve their sentence in open prisons (Lappi-Sepälä 2019, 108). Nevertheless, compared to Catalan prisons, the degree of openness of Nordic open prisons is more limited to such an extent that it is doubtful in some cases that these open prisons really warrant being labelled 'open'.

Likewise, the role that open prisons are granted in each penal system seems to be a key element shaping the different models. Although more research is needed on this issue, I suggest that the greater openness of Catalan open prisons is due to the fact that they are conceived essentially as tools for easing rehabilitation, i.e. as 'back end' or release measures (see Cid \& Ibàñez), rather than as a way of 'humanizing' or 'normalizing' prisons, as occurs in Nordic countries. This link between Catalan open prisons and prisoner rehabilitation and resettlement may help 
explain the importance given to the idea that prisoner supervision in open prisons should be carried out in the local community and the resistance of some professionals to introduce restricted areas. Additionally, some authors have suggested that the Catalan Administration has a 'supervision and probation' ideology in regards of the supervision of people with community sanctions - rather than a 'sentence enforcement' ideology - (Blay \& Larrauri 2017, 199), ${ }^{17}$ which could also explain the openness of their open prisons considering that they are conceived fundamentally as a release measure and so closer in some ways to community penalties than to prisons. In Nordic countries, open prisons also justify their work in terms of rehabilitation and treatment but do not play such an important role in the resettlement or release process, which instead is mainly seen as the task of parole and other measures including halfway houses and electronic monitoring ${ }^{18}$ (see the case of Denmark in Olesen \& Storgaard 2016 and Storgaard 2019, Finland in Lappi-Seppälä 2019, Norway in Johnsen \& Fridhov 2019 and Sweden in Persson \& Svensson 2019).

\section{Summary}

There is an abundant body of literature on closed prisons that provides good evidence of the psychological and social effects of imprisonment in closed prisons on a person. Although no studies exist demonstrating that open prisons are in fact more effective (Birk 2011, 8), it is reasonable to think that they are a more desirable alternative to locking someone up for 24 hours a day (open prisons are, nevertheless, still prisons of one kind or another; Shammas 2015). Different types of open prisons exist in different countries but we still lack enough information to be able to understand what effects each type of open prison has, which types of open prison are the most effective, and what role they should play within the overall penal system. This article presents the Catalan open prisons model, and is an attempt to stimulate comparative discussion and literature on the subject, based on the presentation of some concerns and controversial issues regarding open

17. According to the authors, the General Administration of the State would have a 'more sentence enforcement' ideology, which indeed coincides with the fact that it has much less prisoners in open conditions and their open prisons place many restrictions to them (see Marti 2019).

18. I am only referring to back-door measures and not front-door measures such as the Probation Service, since open prisons in the Nordic countries and Catalonia are only part of the first group. For a complete view of each penalty system, both types of measures should be considered. 
prisons. This work may have raised more questions than it has answered, for example, what degree of openness is most appropriate for an open prison? What are the consequences of having semi-open or closed wings in open prisons? Does the 'pure' open prison model have the capability to be applied to more prisoners bearing in mind prison Administration' aversion to taking risks (Pennington \& Crewe 2015,12$)$ ? The existence of such fundamental doubts may engender a sense of frustration, but at the same time they can be considered as 'restarting points' for investigating further the subject of open prisons and widening the debate on the models of 'semi-imprisonment', which is essential if we are to ensure that the penal systems become respectful of basic human rights and therefore more open.

\section{Bibliography}

Birk, Anne Okkels. 2011. Open prisons - will they last? Danish Institute for Study Abroad, 11 pp.

Blay, Ester \& Elena Larrauri. 2016. 'Community punishments in Spain: A tale of two administrations'. Pp. 191-208 en Community punishment. European perspectives, edited by G. Robinson \& F. McNeill. Routledge, 254 pp. https://doi.org/10.4324/9781315768489-11

Capdevila, Manel (coord.) et al. 2014. La libertad condicional en Cataluña [Parole system in Catalonia]. Centre d'Estudis Jurídics i Formació Especialitzada, 332 pp.

Cid, José \& Aina Ibàñez. 2019. 'Prisoner resettlement in Spain - Good practices for earlyreleased prisoners and prisoners lost in transition that fully serve their sentence'. Pp. 313-327 in Prisoner Resettlement in Europe, edited by F. Dünkel, I., Pruin, A. Storgaard \& J. Weber. Routledge, $530 \mathrm{pp}$.

Chakraburtty, Smita. 2017. The Open Prisons of Rajasthan. Rajasthan State Legal Services Authority, 385 pp.

Cohen, Stanley. 1979. 'The punitive city: Notes on the dispersal of social control'. Contemporary crises 3, pp. 339-363. https://doi.org/10.1007/BF00729115

Crewe, Ben. 2011. 'Depth, weight, tightness: Revisiting the pains of imprisonment'. Punishment \& Society 13, pp. 509-29. https://doi.org/10.1177/1462474511422172

Crewe, Ben. 2015. 'Inside the belly of the penal beast: Understanding the experience of imprisonment'. International Journal for Crime, Justice and Social Democracy 4(1), pp. 50-65. https://doi.org/10.5204/ijcjsd.v4i1.201

Cutiño, Salvador. 2015. 'Clasificación en tercer grado y régimen abierto en el sistema penitenciario español' [Third level category and open regime in the Spanish penitentiary system]. Revista Penal 36 (July), pp. 61-84.

Department of Justice. 2018. Descriptors estadístics [Statistics]. Available at: http://www.gencat.cat/justicia/estadistiques_serveis_penitenciaris/

Fransen, Peter. 2017. 'The rise of the open prisons and the breakthrough of the principle of normalisation from the 1930s until today'. Pp. 81-102 in Scandinavian Penal History, Culture and Prison Practice, edited by P. S. Smith \& T. Uglevik. Palgrave Studies in Prisons and Penology, 529 pp. https://doi.org/10.1057/978-1-137-58529-5_4 
Hornum, Finn. 1988. 'Corrections in Two Social Welfare Democracies: Denmark and Sweden'. The Prison Journal 68(1), pp. 63-82. https://doi.org/10.1177/003288558806800108

Johnsen, Berit \& Inger Marie Fridhov. 2019. Offender resettlement in Norway: positive principles - challenging practices. Lappi-Sepälä Pp. 252-264 in Prisoner Resettlement in Europe, edited by F. Dünkel, I., Pruin, A. Storgaard \& J. Weber. Routledge, 530 pp.

Jones, Howard \& Richard Stockford, assisted by Richard Stockford. 1977. Open prisons. Routledge \& Kegan Paul, 265 pp.

Kriminalforsorgen. 2016. Statistik 2016 [Statistics 2016]. Danish Prison and Probation Service. Available at: www.kriminalforsorgen.dk/Årlige-statistikberetninger-7541.aspx

Kriminalforsorgen. 2016. Statistik 2016 [Statistics 2016]. Danish Prison and Probation Service. Available at: https://www.kriminalforsorgen.dk/wp-content/uploads/2018/12/kriminalforsor gens-statistik-2017-2-udgave.pdf

Lappi-Sepälä, Tapio. 2019. Prisoner resettlement in Finland. Pp. 104-127 in Prisoner Resettlement in Europe, edited by F. Dünkel, I., Pruin, A. Storgaard \& J. Weber. Routledge, 530 pp.

LeBel, Thomas P. \& Shadd Maruna. 2012. 'Life on the Outside: Transitioning from Prison to the Community'. Pp. 657-682 in The Oxford Handbook of Sentencing and Corrections, edited by J. Petersilia \& K. R. Reitz. Oxford University Press, 778 pp. https://doi.org/10.1093/ oxfordhb/9780199730148.013.0027

Martí, Marta. 2018. Un pie en la calle y otro en prisión. El cumplimiento de la pena en semilibertad en prisiones abiertas [One foot in and one foot out: serving a prison sentence in semifreedom conditions in open prisons]. $\mathrm{PhD}$ thesis, Department of Law, Universitat Pompeu Fabra, 308 pp.

Martí, Marta. 2019. 'La ejecución del régimen penitenciario abierto' [The use of open institutions in the Spanish prison system]. Cuadernos de política criminal 127, I, II Época, May, pp. 203-236

McNeill, Fergus \& Kristel Beyens (eds). 2014. Offender supervision in Europe. Palgrave Macmillan, 169 pp. https://doi.org/10.1057/9781137379191

McNeill, Fergus; Raynor, Peter \& Chris Trotter. 2010. Offender supervision: new directions in theory, research and practice. New York: Willan Publishing, $584 \mathrm{pp}$.

Olesen, Anette \& Anette Storgaard. 2016. 'Released from prison in Denmark: Experiences vs. Ambitions'. Pp. 49- 76 in Parole and Beyond, edited by R. Amstrong \& I. Durnescu. Palgrave Studies in Prisons and Penology, 319 pp. https://doi.org/10.1057/978-1-349-95118-5_3

Pennington, Sara \& Ben Crewe. 2015. 'Open Prisons: A Governor's Perspective'. Prison Service Journal 217, pp. 12-13.

Persson, Anders \& Kerstin Svensson. 2019. Prisoner resettlement in Sweden. Pp. 328-342 in Prisoner Resettlement in Europe, edited by F. Dünkel, I., Pruin, A. Storgaard \& J. Weber. Routledge, $530 \mathrm{pp}$.

Reiter, Keramet; Lori Sexton \& Jennifer Sumner. 2017. 'Negotiating imperfet humanity in the Danish penal system'. Pp. 481-507 in Scandinavian Penal History, Culture and Prison Practice, editaded by P. S. Smith \& T. Uglevik. Palgrave Studies in Prisons and Penology, 529 pp. https://doi.org/10.1057/978-1-137-58529-5_20

Shammas, Victor L. 2014. 'The pains of freedom: Assessing the ambiguity of Scandinavian penal exceptionalism on Norway's Prison Island'. Punishment \& Society 16(1), pp. 104-23. https://doi.org/10.1177/1462474513504799 
Shammas, Victor L. 2015. 'A prison without walls: Alternative incarceration in the late age of social democracy'. Prison Service Journal 217, pp. 3-9.

Storgaard, Anette. 2019. Resettlement of prisoners in a Danish context. Pp. 70-85 in Prisoner Resettlement in Europe, edited by F. Dünkel, I., Pruin, A. Storgaard \& J. Weber. Routledge, 530 pp.

Varona, Daniel. In review. 'La suspensión de la pena de prisión en España: razones de una historia de éxito' [Suspended Sentence in Spain: reasons for a history of success].

Walmsley, Roy. 2018. World Prison Population List (12th edition). Institute for Criminal Policy Research, London, 19 pp. 